no bearing on the subject of the high temperatures obtained by breathing through woven material on the bulb of a thermometer, for no one has yet observed that woollen clothing will develop a heat greater than that of the body it covers, viz., $98^{\circ} .5$.

The hygroscopic properties of different materials afford no explanation of the phenomena, for the power of materials to imbibe moisture will not account for an increase of their temperature by breathing through them.

My speculations may be right or wrong; Mr. McNally has not shown them to be either. My facts are not the less true from being incompatible with " ascertained physiological truths," for ascertained physiological truths are only true so long as they are not controverted by other ascertained physiological truths.

My experiments show that the temperature obtained by breathing on the thermometer in the manner described is higher when less caloric is abstracted from the surface of the body, lower when the surface of the body is losing more caloric. Thus on a warm summer day my breath raised the thermometer to $108^{\circ}$, whereas to-day (a cold wet day) it only raised the thermometer up to $103^{\circ}$. Does not this seem to show that respiration is a means of getting rid of the superfluous caloric generated in the body, and that when this excess of caloric cannot be got rid of by the skin it passes off by the breath? R. E. DUDGEON October 9

\section{Selenium}

As the only chance of being able to transmit images of reflection through a conducting wire, in the way sound is repeated to a distance by telephone, appears to lie in the preparation of a fairly transparent sheet of metallic selenium; it may tend to advance the subject if the difficulties experienced in dealing with this substance are mentioned.

Selenium in its vitreous condition melts about $220^{\circ}$ Fahrenheit, and can be drawn out between mica plates over a lamp, to a thin transparent red film. But heated for some time it turns black and granular, apparently absorbing hydrogen, then melts only at $423^{\circ} \mathrm{F}$., and is brittle and intractable. Unfortunately it is only in this crystalline state that its power of conducting electricity appears, and varies with the light under which the selenium is placed.

Prepared in the mass, electrically conducting selenium is as compact as the hardest gas carbon, with the shiny appearance and surface of graphite. How to reduce such a substance to any degree of transparency is perplexing. By reducing it to fine powder, and subjecting the black selenium to severe hydraulic pressure between hot polished steel plates, the desired effect might be produced. Selenium also dissolves freely in chloride of selenium, $\mathrm{Se}_{2} \mathrm{Cl}_{2}$, and precipitates slowly in a botyroidal mass of black selenium. It also separates in the crystalline form from concentrated solutions of selenide of potassium or sodium.

There is some uncertainty as to whether a transparent sheet could be more easily obtained by the method of precipitation, than by mere mechanical treatment. But the investigation is one that requires to be carried out with the aid of a fully equipped laboratory, and is beyond the power of an ordinary experimentalist.

To devise a successful mode of making a black substance like graphite at all translucent, requires a distinct understanding of the reason why bodies are opaque. Something more than an explanation in general terms is needed before camera pictures can be resolved into electric currents, and again integrated upon a receiving plate.

Perhaps some of the readers of NATURe may be able to suggest a method of dealing with selenium that will produce thin transparent sheets capable of conducting electricity.

London, October I6

A. T. F.

\section{Dynastes Hercules}

The reviewer of Ober's "Camps in the Caribbees" (NATURE, vol. xxii. p. 216) appears to doubt the story of the habits of the large Hercules beetle, Dynastes hercules, given by Ober on the authority of his guide. It is nevertheless perfectly true, and I have myself witnessed the occurrence twice in this neighbourhood, where the beetle is not uncommon. In the first instance I noticed it on a branch of Ochroma lagopus, and the second time on a species of Bombax, both very soft-wooded trees. The branches in each case were about thiee-quarters of an inch in diameter, half an inch being formed by the wood. In both cases $I$ saw the performance of the animal most distinctly, just as described by

Ober's guide, and I took not only a piece of the severed branch with me, but secured also the second animal. The noise is not so much produced by the cutting of the branch as by the open wings passing rapidly through the air during the rotation of the beetle. I do not believe there is anything of a sexual call in the manouvre. The beetle wants to get at the abundant juice of the young branches. It is called in this country aserrador, i.e. sazvyer. Golofa porteri, an allied insect of the same family as Lamellicornes, behaves in a similar way, but chooses of course thinner branches.

Carácas September 9

A. ERNST

\title{
What is Alrese?
}

In the large Encyclopédie published by Diderot and d'Alembert, vol. xii. p. 224 (edit. in folio) there is mentioned amongst the substances used for poisoning water to catch the fish, l'herbe qu'on appelle l'ALRESE. Littré has no such word, nor anything like it, nor indeed any other lexicographer I am able to consult here. I should be much obliged for any information on this name, or the plant referred to.

Carácas, September 9

\section{Rainfall of Sierra Leone}

As I believe there is little account taken of this climate at home, and as perhıps it might interest you, I send you an account of one day's rainfall this month, which is an excessive amount even for Freetown, and equal to one-third the whole year's rainfall for Dublin, I believe :-

$$
\begin{aligned}
& \text { Rainfall registered in the Colonial Hospital, Freetown, } 50 \text { feet } \\
& \text { above Sea-level } \\
& \text { From } 6 \text { a.m. to } 4 \text { p.m. September II } \ldots . . . \quad \begin{array}{ccc}
\text { Inches. } \\
6 * 35
\end{array} \\
& \text { From } 4 \text { p.m. to } 6 \text { a.m. September } 12 \text {... }
\end{aligned}
$$

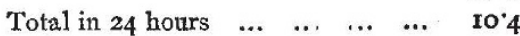

September 16

Colonial Surgeon

\section{An Octopus}

I INCLOSE an account of an enormous octopus which was thrown on the shore at Kilkee, Co. Clare, in the last great storm. As strangers find my uncle's hand very hard to read, I have copied his letter.

Ardanoir Foynes

\section{G. O'BRIEN}

"Saturday, October 9, 1880

"I am sorry you were not at Kilkee when a great octopus was stranded on the side of the Duggerna reef on Thursday last. Its arms had been partially broken : there were eight of them, each as thick as a strong man's upper arm, and beneath each were two rows of suckers like cupping-glasses, more than a shilling size in circuit. When perfect, each of these arms must have been from twelve to fifteen feet long, and from the point of one arm to that of its opposite was a length of nearly thirty feet. The animal's length from the insertion of its suckers to the end of its body must have been nearly twenty feet, perhaps more. Its mouth, like a parrot's beak, was as large as two joined hands of a large man with the fingers outstretched. It weighed about $4 \mathrm{cwt}$. Its head was $\mathrm{I} \frac{1}{2}$ inch in diameter, about three feet long; its eyes of the size of the inner circuit of a breakfast-plate. A monster. The under colour that of the under side of a turbot." -(From a letter of the Rev. R. J. GABBETT.)

\section{SYNTHESIS OF CITRIC ACID}

$\Lambda \mathrm{S}$ we intimated last week, another brilliant synthesis $A$ has recently been accomplished in the domain of organic chemistry. Messrs. Grimaux and Adam have succeeded in building up the characteristic acid of lemons from glycerin. Glycerin may be regarded as trihydroxypropane, $\mathrm{C}_{3} \mathrm{H}_{5}(\mathrm{OH})_{3}$, and citric acid as hydroxypropanetricarboxyllic acid, $\mathrm{C}_{3} \mathrm{H}_{4}(\mathrm{OH})\left(\mathrm{CO}_{2} \mathrm{H}\right)_{3}$. To convert glycerin into citric acid it was therefore necessary to replace two hydroxyl groups, and one hydrogen atom, by the group $\mathrm{CO}_{2} \mathrm{H}$ (carboxyl). This was done as follows:-By the action of hydrochloric acid on glycerin, dichlorhydrin, 